\title{
The Glacidorbidae (Mollusca: Gastropoda: Heterobranchia) of Australia
}

\author{
W.F. PONDER AND G.J. AVERN \\ Centre for Evolutionary Research, Australian Museum, 6 College Street, Sydney NSW 2010, Australia \\ winstonp@austmus.gov.au
}

\begin{abstract}
The heterobranch gastropod family Glacidorbidae (?Pulmonata) is known only from temperate Australia and Chile. The Australian taxa are reviewed and three new genera, Benthodorbis, Striadorbis and Tasmodorbis are described based on differences in their shells, especially the protoconchs, and in their opercula and radulae. Nineteen species of Australian glacidorbids are recognised, all but four of them new. Of the four Australian species previously included in Glacidorbis, only two, G. hedleyi (Iredale) from New South Wales and Victoria, and G. occidentalis Bunn \& Stoddart from south Western Australia, are retained in that genus. Eleven new species of Glacidorbis are described, seven from Tasmania (G. bicarinatus, G. catomus, G. atrophus, G. decoratus, G. costatus, G. tasmanicus and G. circulus), one (G. isolatus) from New South Wales, two (G. otwayensis and G. rusticus) from Victoria and one (G. troglodytes) from South Australia. Striadorbis contains the Tasmanian S. pedderi (Smith), and two new species, $S$. spiralis from western Victoria and S. janetae from Tasmania. Benthodorbis contains two species, both from old lakes in Tasmania; B. pawpela (Smith) from Great Lake and $B$. fultoni from Lake Sorell. Tasmodorbis contains a single species found in western Tasmania, T. punctatus, unique in having internal shell pores. Glacidorbis costatus is known only from Pulbeena Swamp in NW Tasmania and appears to be recently extinct, possibly as a result of draining of the swamp in the early part of this century. A cladistic analysis with the South American member of the family, Gondwanorbis, as the outgroup, supports the monophyly of the genera recognised.
\end{abstract}

Ponder, W.F., \& G.J. Avern, 2000. The Glacidorbidae (Mollusca: Gastropoda: Heterobranchia) of Australia. Records of the Australian Museum 52(3): 307-353.

Small-sized Australian freshwater molluscs have, in recent years, been shown to be much more diverse than previously imagined. Nearly all of this diversity is contained within the caenogastropod family Hydrobiidae (see Ponder, 1991 and Ponder \& de Keyzer, 1998 for review), while other families of small-sized freshwater gastropods such as the Assimineidae, Bithyniidae, Planorbidae and Glacidorbidae are known to contain a several undescribed taxa. This paper revises the taxa included in the Glacidorbidae.
A tiny flat-spired gastropod, Glacidorbis hedleyi, was described by Iredale (1943) from Blue Lake, Mount Kosciuszko, NSW. Iredale included his new taxon in the basommatophoran pulmonate family Planorbidae but Meier-Brook \& Smith (1976) showed that the genus was operculate and reviewed the known species. While they suggested similarities with the hydrobiids, they did not make any decision on the placement of the genus pending anatomical investigation and Smith (1979) placed 